\title{
Ammonia, Methane, and Nitrous Oxide Emission from Pig Slurry Applied to a Pasture in New Zealand
}

\author{
Robert R. Sherlock, Sven G. Sommer,* Rehmat Z. Khan, C. Wesley Wood, Elizabeth A. Guertal, \\ John R. Freney, Christopher O. Dawson, and Keith C. Cameron
}

\begin{abstract}
Much animal manure is being applied to small land areas close to animal confinements, resulting in environmental degradation. This paper reports a study on the emissions of ammonia $\left(\mathrm{NH}_{3}\right)$, methane $\left(\mathrm{CH}_{4}\right)$, and nitrous oxide $\left(\mathrm{N}_{2} \mathrm{O}\right)$ from a pasture during a 90-d period after pig slurry application $\left(60 \mathrm{~m}^{3} \mathrm{ha}^{-1}\right)$ to the soil surface. The pig slurry contained $6.1 \mathrm{~kg}$ total $\mathrm{N} \mathrm{m}^{-3}, 4.2 \mathrm{~kg}$ of total ammoniacal nitrogen (TAN $=\mathrm{NH}_{3}+\mathrm{NH}_{4}$ ) $\mathrm{m}^{-3}$, and $22.1 \mathrm{~kg} \mathrm{C} \mathrm{m}^{-3}$, and had a $\mathrm{pH}$ of 8.14. Ammonia was lost at a fast rate immediately after slurry application $\left(4.7 \mathrm{~kg} \mathrm{~N} \mathrm{ha}^{-1} \mathrm{~h}^{-1}\right)$, when the $\mathrm{pH}$ and TAN concentration of the surface soil were high, but the loss rate declined quickly thereafter. Total $\mathrm{NH}_{3}$ losses from the treated pasture were $57 \mathrm{~kg} \mathrm{~N} \mathrm{ha}^{-1}(22.5 \%$ of the TAN applied). Methane emission was highest $\left(39.6 \mathrm{~g} \mathrm{C} \mathrm{ha}^{-1} \mathrm{~h}^{-1}\right)$ immediately after application, as dissolved $\mathrm{CH}_{4}$ was released from the slurry. Emissions then continued at a low rate for approximately 7 d, presumably due to metabolism of volatile fatty acids in the anaerobic slurry-treated soil. The net $\mathrm{CH}_{4}$ emission was $1052 \mathrm{~g} \mathrm{C} \mathrm{ha}^{-1}(\mathbf{0 . 0 8} \%$ of the carbon applied). Nitrous oxide emission was low for the first $14 \mathrm{~d}$ after slurry application, then showed emission peaks of $7.5 \mathrm{~g} \mathrm{~N}$ $h^{-1} h^{-1}$ on Day 25 and $15.8 \mathrm{~g} \mathrm{~N} \mathrm{ha}^{-1} h^{-1}$ on Day 67, and decline depending on rainfall and nitrate $\left(\mathrm{NO}_{3}\right)$ concentrations. Emission finally reached background levels after approximately $90 \mathrm{~d}$. Nitrous oxide emission was $7.6 \mathrm{~kg} \mathrm{~N} \mathrm{ha}^{-1}(2.1 \%$ of the $\mathrm{N}$ applied). It is apparent that of the two major greenhouse gases measured in this study, $\mathrm{N}_{2} \mathrm{O}$ is by far the more important tropospheric pollutant.
\end{abstract}

$\mathrm{T}$ HE NEED TO increase food production to keep pace with population growth and changing consumer tastes has led to a large increase in animal production (FAOSTAT, 1999), and problems related to disposing massive dung and urine quantities. The problem is exacerbated by disassociation of crop and livestock production (Bouwman and Booij, 1998; Ke, 1998). This has meant that the animal wastes cannot be returned to fields where feed was grown and used to provide nutrients for succeeding crops. Consequently, much animal manure is being applied to small land areas close to animal confinements, resulting in environmental degradation (Burton, 1997).

Applying manure or slurries to agricultural land can lead to ground water contamination by nitrate $\left(\mathrm{NO}_{3}\right)$

R.R. Sherlock and K.C. Cameron, Soil Plant and Ecological Sciences Division, P.O. Box 84, Lincoln Univ., Canterbury, New Zealand. S.G. Sommer, Dep. of Agricultural Engineering, Danish Institute of Agricultural Sciences, P.O. Box 536, DK-8700, Horsens, Denmark. R.Z. Khan (deceased), from 1995 to 1998 Ph.D. student at Soil Plant and Ecological Sciences Division, P.O. Box 84, Lincoln Univ., Canterbury, New Zealand. C.W. Wood and E.A. Guertal, Dep. of Agronomy and Soils, 236 Funchess Hall, Auburn University, AL 36849-5412. J.R. Freney, CSIRO Plant Industry, G.P.O. Box 1600, Canberra, ACT, Australia. C.O. Dawson, Animal and Food Sciences Division, P.O. Box 84, Lincoln Univ., Canterbury, New Zealand. Received 19 June 2001. *Corresponding author (SvenG.Sommer@agrsci.dk).

Published in J. Environ. Qual. 31:1491-1501 (2002). after nitrification of the ammonium nitrogen $\left(\mathrm{NH}_{4}-\mathrm{N}\right)$ present, and emission of $\mathrm{NH}_{3}$ (European Centre for Ecotoxicology and Toxicology of Chemicals, 1994), $\mathrm{CH}_{4}$ (Chadwick and Pain, 1997) and $\mathrm{N}_{2} \mathrm{O}$ (Jarvis et al., 1994), all of which contribute to climate change. Methane and $\mathrm{N}_{2} \mathrm{O}$ are greenhouse gases that contribute directly to climate change (Intergovernmental Panel on Climate Change, 1996). Ammonia, after deposition on land surfaces and water bodies and nitrification, acts as a secondary source of $\mathrm{N}_{2} \mathrm{O}$ (Mosier et al., 1998), and may also decrease the capacity of soils to absorb $\mathrm{CH}_{4}$ and act as a sink for this gas (Mosier et al., 1991, 1996). However, the magnitude of these direct effects and interactions is not known with certainty.

The Intergovernmental Panel on Climate Change (IPCC) has been coordinating the development of inventory methodologies for greenhouse gases (Intergovernmental Panel on Climate Change, 1997) and this has revealed the lack of information required to define appropriate factors for $\mathrm{CH}_{4}$ and $\mathrm{N}_{2} \mathrm{O}$ emission from different sources. For example, there is considerable doubt as to which emission factor should be used for calculating $\mathrm{N}_{2} \mathrm{O}$ emission from redeposited $\mathrm{NH}_{3}$ and the various organic forms of $\mathrm{N}$ used in agriculture (Mosier et al., 1998). In addition, the Intergovernmental Panel on Climate Change (1997) protocol assumes there is no $\mathrm{CH}_{4}$ emission from animal slurry applied in the field, whereas Chadwick and Pain (1997) and Sommer et al. (1996) have shown in laboratory studies that $\mathrm{CH}_{4}$ is emitted following pig and dairy slurry application to soil.

Developing strategies to reduce $\mathrm{CH}_{4}$ and $\mathrm{N}_{2} \mathrm{O}$ emissions from agricultural land requires an understanding of the production, emission, and consumption of these gases. In particular, studies are required on the interactions between these gases because it is of concern that strategies to reduce emission of one gas may increase emission of the other (Intergovernmental Panel on Climate Change, 1996). Consequently, it is necessary to measure emission of all three gases simultaneously in the system under study. This paper reports a study on $\mathrm{NH}_{3}, \mathrm{CH}_{4}$, and $\mathrm{N}_{2} \mathrm{O}$ emission from a pasture under conditions recommended by the Intergovernmental Panel on Climate Change (1997), after pig (Sus scrofa) slurry application, to assist in defining suitable factors to calculate $\mathrm{CH}_{4}$ and $\mathrm{N}_{2} \mathrm{O}$ emissions. Micrometeorological methods are available for accurately measuring $\mathrm{NH}_{3}$ volatilization in the field (Denmead et al., 1974; Denmead, 1983; Wilson et al., 1983; Schjoerring et al., 1992; Sherlock et al., 1995; Wood et al., 2000). Various chamber procedures for $\mathrm{NH}_{3}$ have also been implemented in

Abbreviations: IPCC, Intergovernmental Panel on Climate Change TAN, total ammoniacal nitrogen $\left(\mathrm{NH}_{3}+\mathrm{NH}_{4}\right)$. 
the field, but these can introduce experimental artifacts that alter the dynamics and extent of $\mathrm{NH}_{3}$ volatilization (Freney et al., 1983; Black et al., 1985). Ammonia is very reactive with water compared with $\mathrm{CH}_{4}$ and $\mathrm{N}_{2} \mathrm{O}$ (Liss and Slater, 1974). The elevated $\mathrm{NH}_{3}$ concentration in a static chamber will, consequently, reduce $\mathrm{NH}_{3}$ emission from the soil covered by the chamber. The $\mathrm{NH}_{3}$ emission, therefore, was measured with a micrometeorological mass balance technique (Wilson et al., 1983) that does not affect the $\mathrm{NH}_{3}$ concentration above the soil amended with slurry. In contrast with $\mathrm{NH}_{3}$, static chambers are the preferred current method for measuring surface fluxes of both $\mathrm{CH}_{4}$ and $\mathrm{N}_{2} \mathrm{O}$ since these gases are less reactive with water and are much less affected by increases in chamber headspace concentrations (Mosier et al., 1991). Also in contrast to $\mathrm{NH}_{3}$, it is generally very difficult to detect the small concentration gradients of $\mathrm{N}_{2} \mathrm{O}$ and $\mathrm{CH}_{4}$ above the soil surface when these gases are being emitted. This is necessary for implementing micrometeorological techniques. Nevertheless, when comparisons between methods have been possible, little if any difference is observed between $\mathrm{N}_{2} \mathrm{O}$ emissions measured with a micrometeorological technique and static chambers (Fowler et al., 1997). Consequently, we decided to use static chambers to measure $\mathrm{N}_{2} \mathrm{O}$ and $\mathrm{CH}_{4}$ fluxes in this study.

\section{MATERIALS AND METHODS \\ Study Site}

Gas emission was studied at a site $2 \mathrm{~km}$ from Lincoln University on the South Island of New Zealand $\left(172^{\circ} 30^{\prime}\right.$ E, $43^{\circ} 38^{\prime}$ $S)$. The study site was a pasture having $<1 \%$ slope on which sheep-grazing was discontinued two weeks prior to the experiment start. The pasture was a mixture of perennial ryegrass (Lolium perenne L.), white clover (Trifolium repens L.) and weeds. The pasture covered the soil completely and its height was approximately $5 \mathrm{~cm}$ during the course of the experiment. The soil at the site is classified as a Wakanui silt loam (Udic Dystrochrept) (Kear et al., 1967). Pig slurry was applied to a 20-m-radius circular plot at the rate of $60 \mathrm{~m}^{3} \mathrm{ha}^{-1}$ by a tanker fitted with a spreading bar at $1030 \mathrm{~h}$ on 9 Aug. 1995. Some properties of the soil and slurry are given in Table 1 .

During the initial $10 \mathrm{~d}$ of $\mathrm{NH}_{3}$ emission measurements, wind speed at $0.5 \mathrm{~m}$ was measured with a cup anemometer (Sensitive Anemometer T16108/2; Casella London Ltd., London) with a low stalling speed; soil temperatures at a $2.5-\mathrm{cm}$ depth (LM

Table 1. Properties of the pasture soil and slurry used in the study.

\begin{tabular}{|c|c|c|}
\hline Property & Soil & Slurry \\
\hline Soil classification & Wakanui silt loam & \\
\hline Clay, \% & 27 & \\
\hline Silt, \% & 67 & \\
\hline Sand, \% & 6 & \\
\hline & 5.36 & 8.14 \\
\hline Amount applied, $\mathbf{m}^{3} \mathbf{h a}^{-1}$ & & 60 \\
\hline Density, $\mathbf{k g ~ m}^{-3}$ & & 1053 \\
\hline Dry matter, $\mathrm{kg} \mathrm{m}^{-3}$ & & 43.8 \\
\hline Total C & $25.6 \mathrm{~g} \mathrm{~kg}^{-1}$ & $22.1 \mathrm{~kg} \mathrm{~m}^{-3}$ \\
\hline Total $\mathbf{N}$ & $2.8 \mathrm{~g} \mathrm{~kg}^{-1}$ & $6.1 \mathrm{~kg} \mathrm{~m}^{-3}$ \\
\hline TAN $\dagger$ & $0.84 \mathrm{mg} \mathrm{kg}^{-1}$ & $4.2 \mathrm{~kg} \mathrm{~m}^{-3}$ \\
\hline Nitrate $\mathbf{N}$ & $2.9 \mathrm{mg} \mathrm{kg}^{-1}$ & 0 \\
\hline $\mathrm{CEC} \ddagger, \mathrm{cmol}\left[\mathrm{Na}^{+}\right] \mathrm{kg}^{-1}$ & $15.4^{\circ}$ & \\
\hline
\end{tabular}

$\dagger$ Total ammoniacal nitrogen.

$\$$ Cation exchange capacity.
35 CZ; R.S. Components, Corby, UK) were measured and stored as 30-min averages on a datalogger (Campbell Scientific Ltd., Shepshed, UK), and wind direction was determined by a wind vane (Ota Keiki Seisakusho Co. Ltd., Tokyo). During the entire 0- to 90-d period of $\mathrm{CH}_{4}$ and $\mathrm{N}_{2} \mathrm{O}$ emission measurements, air temperature data $(2 \mathrm{~m})$, soil temperatures $(10 \mathrm{~cm})$, and rain and pan evaporation from a climate station (Crop \& Food Research, Lincoln, NZ) within $400 \mathrm{~m}$ of the field were used.

\section{Ammonia Emission}

Measurements of $\mathrm{NH}_{3}$ emission from the slurry-treated plot commenced immediately after slurry application on 9 August and continued for $10 \mathrm{~d}$ until $\mathrm{NH}_{3}$ emission returned to background levels. The fluxes were determined by the mass balance micrometeorological method described in Sherlock et al. (1995). The mass balance method equates the average surface flux density of $\mathrm{NH}_{3}$ from the circular plot amended with pig slurry to the difference between the integrated horizontal flux at a known downwind distance and that at the upwind edge (Wilson et al., 1983). With passive Leuning samplers (Leuning et al., 1985) mounted at several heights $z(\mathrm{~m})$, on masts placed at the upwind edge and at the center of the plot (radius $20 \mathrm{~m}$ ), the net horizontal flux $\left(F, \mathrm{~g} \mathrm{~m}^{-2} \mathrm{~s}^{-1}\right)$ is derived from:

$$
F=\frac{1}{x}\left(\sum_{0}^{z} \overline{u c}_{\mathrm{dw}}-\overline{u c}_{\mathrm{uw}} \Delta z\right)
$$

where $x$ is the radius of the circular plot $(20 \mathrm{~m}), \overline{u c}$ is the mean horizontal flux ( $u$ is wind speed, $\mathrm{m} \mathrm{s}^{-1}$ and $c$ is $\mathrm{NH}_{3}$ concentration, $\mathrm{g} \mathrm{m}^{-3}$ ) measured by each sampler at the downwind (dw) or upwind (uw) edge of the treated area. According to Leuning et al. (1985), $\overline{u c}$ is derived from:

$$
\overline{u c}=\frac{M}{A t}
$$

where $M$ is the mass of $\mathrm{NH}_{3}-\mathrm{N}$ collected ( $\mathrm{g}$ ) by oxalic acid coating the interior of the Leuning sampler during the sampling period $t(\mathrm{~s})$, and $A$ is the effective cross-sectional area of the sampler $\left(\mathrm{m}^{2}\right)$ determined in wind-tunnel calibrations. After exposure, the coating was dissolved in $0.040 \mathrm{~L}$ deionized water and the $\mathrm{NH}_{4}-\mathrm{N}$ concentration $(M)$ determined on a 0.0204 aliquot with an $\mathrm{NH}_{3}$ specific ion electrode (HNU Systems, Newton, MA). The samplers were mounted on a mast in the center of the field at $0.2,0.4,0.8,1.2,2.4$, and $3.6 \mathrm{~m}$ above the soil surface. Background measurements were made with samplers placed at $0.4 \mathrm{~m}$ and $1.2 \mathrm{~m}$ on a mast located on the upwind side of the treated area. The ammonia samplers were changed three times each day during the first $5 \mathrm{~d}(0900$ $1300,1300-1700$, and $1700-0900 \mathrm{~h}$ ) and once a day (at $1300 \mathrm{~h}$ ) during the period 6 to $10 \mathrm{~d}$. (Note that on the day of slurry application the first sampling period extended from 1030 to 1300 h only).

As a backup, $\mathrm{NH}_{3}$ flux was also determined with a second design of passive sampler (Ferm tubes) consisting of two parallel sampler units, each of which had three glass tubes (inner diameter $7 \mathrm{~mm}$ and lengths of 100, 100, and $23 \mathrm{~mm}$ ) joined by silicone tubing (Schjoerring et al., 1992). The interior surface of the two $100-\mathrm{mm}$ tubes was coated with oxalic acid for approximately $70 \mathrm{~mm}$ of the tube length. Glued to the end of the $23-\mathrm{mm}$ tube was a stainless steel nozzle with a central hole of 1-mm diameter.

After exposure, the tubes were disconnected and the two $100-\mathrm{mm}$ tubes analyzed separately. The coating was dissolved in $0.003 \mathrm{~L}$ deionized water and the $\mathrm{NH}_{4}-\mathrm{N}$ content determined 
by the indophenol blue colorimetric method with a flow injection analyzer (Tecator [Höganäs, Sweden] FIAstar).

The Ferm tube flux samplers were mounted on four masts at $0.2,0.6,1.2,2.4$, and $3.6 \mathrm{~m}$ above ground level, positioned at $0,90,180$, and $270^{\circ}$ angles around the circumference of the circular plot. The samplers continuously integrate the horizontal ammonia flux at the various heights. After analysis of the ammonia content in the tubes facing the $\mathrm{NH}_{3}$ source (exposed tubes) and surroundings (background tubes), the net horizontal flux can be calculated for each measurement height. Knowing the net horizontal ammonia flux, the vertical flux from the experimental plot was obtained by applying mass balance equations.

The average horizontal $\mathrm{NH}_{3}$ flux $\left(F_{h m}, \mu \mathrm{g} \mathrm{NH}_{3}-\mathrm{N} \mathrm{m}^{-2} \mathrm{~s}^{-1}\right)$ through two glass tubes facing in the same direction at each measuring height $(h)$ on each mast $(m)$ either away from (background tubes) or toward (exposed tubes) the $\mathrm{NH}_{3}$ source was calculated by the following equation:

$$
F_{h m}=\frac{\left(C_{1}+C_{2}\right) V}{2 \times \pi \times r^{2} \times K \times \Delta t}
$$

where $C_{1}$ and $C_{2}$ are the concentrations of $\mathrm{NH}_{4}\left(\mu \mathrm{g} \mathrm{NH} \mathrm{NH}_{4}-\mathrm{N}\right.$ $\mathrm{L}^{-1}$ ) in either the two exposed tubes or the background tubes, $V$ is the volume of deionized water used to dissolve the $\mathrm{NH}_{4}$ sorbed in the tubes $(0.003 \mathrm{~L}), r$ is the radius of the hole in the stainless steel disc $(0.0005 \mathrm{~m}), t$ is the time (s) between the start and conclusion of the measurement, and $K$ is a correction factor $(K=0.77$; Schjoerring et al., 1992).

The horizontal net flux $\left(F_{\text {net, }}, \mu \mathrm{g} \mathrm{NH} \mathrm{NH} \mathrm{m}_{3} \mathrm{~N}^{-1}\right)$ at each height was calculated by the equation (Schjoerring et al., 1992):

$$
F_{\text {net, } \mathrm{h}}=\sum_{m=1}^{m=4}\left(F_{h m, \mathrm{~s}}-F_{h m, \mathrm{~b}}\right)
$$

where $F_{h m, \mathrm{~s}}$ is the $\mathrm{NH}_{3}$ flux from the source measured with the exposed tubes and $F_{h m, \mathrm{~b}}$ is the flux from the background measured with the background tubes at each measuring height $(h)$ and at each mast $(m)$.

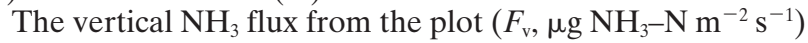
was calculated by stepwise summation of the horizontal net flux over the height intervals represented by the flux samplers (Schjoerring et al., 1992):

$$
F_{\mathrm{v}}=\frac{1}{x_{h=1}^{h=5}} \sum_{\text {net, } \mathrm{h}} \Delta h
$$

where $\Delta h$ is the height interval represented by the flux samplers and $x(20 \mathrm{~m})$ is the diameter of the experimental plot.

\section{Methane and Nitrous Oxide Emissions}

Measurements of $\mathrm{CH}_{4}$ and $\mathrm{N}_{2} \mathrm{O}$ emission with a closed chamber technique (Hutchinson and Mosier, 1981) commenced immediately following slurry application on 9 August and continued until 7 November. Emission was measured from microplots formed by pushing steel cylinders $(24-\mathrm{cm}$ diameter) into the soil. Five cylinders were placed in the slurry-treated plot and four cylinders were located on untreated soil upwind of the plot. Cylindrical gas-tight lids, having a headspace height of $10 \mathrm{~cm}$ and fitted with rubber septa for sampling, were attached to the steel cylinders during gas emission measurements, but were left open between measurements. Changes in headspace $\mathrm{CH}_{4}$ and $\mathrm{N}_{2} \mathrm{O}$ concentrations were used for calculating gas fluxes. Gas samples were collected with $50-\mathrm{mL}$ syringes at 0 , 10, and 20 min after lid closure. Samples were collected twice a day during the first $5 \mathrm{~d}$, twice every second day during the period 5 to $11 \mathrm{~d}$, once a day during the period 11 to $60 \mathrm{~d}$, and once every second day during 60 to $90 \mathrm{~d}$. Emission was measured at 1000 and $1600 \mathrm{~h}$ when two measurements were taken per day and at $1200 \mathrm{~h}$ on the other measurement days.

The gas samples were injected via a 10-port sampling valve into a carrier stream of $\mathrm{N}_{2}$, and a four port-switching valve directed the carrier gas stream to either of two gas chromatographs for $\mathrm{CH}_{4}$ or $\mathrm{N}_{2} \mathrm{O}$ determination. Methane was determined on an SRI (Torrance, CA) instrument equipped with a flame ionization detector. Nitrous oxide was determined on a Varian (Walnut Creek, CA) Aerograph Series 2800 equipped with a ${ }^{63} \mathrm{Ni}$ electron-capture detector (Pye-Unicam, Cambridge, $\mathrm{UK}$ ) and a stainless steel column (4-m length, 3-mm internal diameter) packed with Porapak Q (80/100 mesh) (Alltech Associates, Deerfield, IL). Detector and column temperatures were 350 and $20^{\circ} \mathrm{C}$, respectively.

In general, $\mathrm{CH}_{4}$ and $\mathrm{N}_{2} \mathrm{O}$ fluxes were calculated with the logarithmic equation described by Hutchinson and Mosier (1981). At times when gas fluxes were small, they were determined with a linear equation.

\section{Soil and Manure Analysis}

Pig slurry was sampled from the slurry spreader and stored at $4^{\circ} \mathrm{C}$ until analysis. Pig slurry dry matter was determined gravimetrically, slurry density by weighing an aliquot of $20 \mathrm{~mL}$ in a graduated flask, total $\mathrm{N}$ and total $\mathrm{C}$ with a mass spectrometer (Tracermass; Europa Scientific, Crewe, UK), and $\mathrm{NH}_{4}$ and $\mathrm{NO}_{3}$ on a flow injection analyzer (Tecator FIAstar).

Soil samples $(0-5 \mathrm{~cm})$ were collected immediately before slurry application, three times per day for the first $5 \mathrm{~d}$ after application, once per day from 6 to $10 \mathrm{~d}$, three times per week during 10 to $20 \mathrm{~d}$, twice per week during 20 to $60 \mathrm{~d}$, and once every second week during 60 to $90 \mathrm{~d}$. Five replicate samples were taken on each occasion. Soil samples were well mixed in a field laboratory at the site and stored at temperatures less than $4^{\circ} \mathrm{C}$ until analysis. The $\mathrm{pH}$ of soil and canopy surfaces was measured with a portable $\mathrm{pH}$ meter and a flat surface $\mathrm{pH}$ electrode. Soil $\mathrm{NO}_{3}, \mathrm{TAN}$, and volatile fatty acids were extracted with $2 \mathrm{M} \mathrm{KCl}(2 \mathrm{KCl}$ to 1 soil, w/w). These suspensions were shaken for $30 \mathrm{~min}$ and filtered through Whatman (Maidstone, UK) \#42 filter paper. Ten milliliters of each sample was used to determine $\mathrm{NO}_{3}-\mathrm{N}$ and TAN, with standard colorimetric techniques (Keeney and Nelson, 1982), on a FIAstar 5010 analyzer (Tecator). Five milliliters of the extract was used to determine volatile fatty acids. To each aliquot, $0.5 \mathrm{~mL}$ of $0.3 \mathrm{M}$ oxalic acid and $0.5 \mathrm{~mL}$ of pivalic acid $(25000$ $\mathrm{mg} \mathrm{L}^{-1}$ in $0.3 M$ oxalic acid) as an internal standard were added. The mixture was centrifuged at $16000 \mathrm{rpm}$ for $10 \mathrm{~min}$, the supernatant was passed through a $0.45-\mu \mathrm{m}$ filter, and the resulting filtrates were stored at $-18^{\circ} \mathrm{C}$ until analysis. The $\mathrm{C}_{2}-\mathrm{C}_{5}$ fatty acids in the filtrates were determined on a Shimadzu (Kyoto, Japan) GC-7A gas chromatograph equipped with a flame ionization detector $\left(140^{\circ} \mathrm{C}\right)$ and a glass column (1.8-m length, 4-mm internal diameter) packed with Tenax GC (60/80) and FAL-M (Buchem BV, Apeldoorn, the Netherlands). Injector and oven temperatures were maintained at 210 and $136^{\circ} \mathrm{C}$, respectively. The carrier gas was $\mathrm{N}_{2}$ adjusted

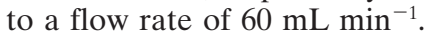

\section{Calculations and Statistics}

It has been shown that $\mathrm{NH}_{3}$ loss from both flooded and nonflooded fields is determined by two main variables, the equilibrium $\mathrm{NH}_{3}$ concentration and the wind speed (Freney et al., 1985; De Datta et al., 1989; Sherlock et al., 1995). Ammonia is lost from solution at the soil's surface when the $\mathrm{NH}_{3}$ gas concentration in equilibrium with the solution is greater than that of the atmosphere. Increasing wind speed increases 
the volatilization rate by promoting more rapid $\mathrm{NH}_{3}$ transport away from the surface. Immediately after applying animal slurry, urine, or fertilizer, the equilibrium $\mathrm{NH}_{3}$ concentration is much greater than that in the ambient atmosphere, thus the latter can be ignored and the relationship between the main variables is described by:

$$
F \propto u\left[\mathrm{NH}_{3}\right]_{\text {gas }}
$$

where $F$ is the vertical flux of $\mathrm{NH}_{3}\left(\mu \mathrm{g} \mathrm{N} \mathrm{m}{ }^{-2} \mathrm{~s}^{-1}\right)$, $\left[\mathrm{NH}_{3}\right]_{\text {gas }}$ is the concentration of $\mathrm{NH}_{3}$ gas $\left(\mu \mathrm{g} \mathrm{N} \mathrm{m}{ }^{-3}\right)$ in equilibrium with $\mathrm{NH}_{3}$ dissolved in the soil solution $\left(\left[\mathrm{NH}_{3}\right]_{\text {solution }}, \mu \mathrm{g} \mathrm{N} \mathrm{m}^{-3}\right)$, and $u$ is wind speed $\left(\mathrm{m} \mathrm{s}^{-1}\right)$. The equilibrium ammonia concentration $\left(\left[\mathrm{NH}_{3}\right]_{\text {gas }}\right)$ is determined from the TAN concentration, $\mathrm{pH}$, and temperature of the solution at the soil surface (Emerson et al., 1975; Hales and Drewes, 1979; Denmead et al., 1982; Sherlock et al., 1995) as follows:

$$
\begin{aligned}
{\left[\mathrm{NH}_{3}\right]_{\text {gas }} } & =\left[\mathrm{NH}_{3}\right]_{\text {solution }} / K_{\mathrm{H}} \\
{\left[\mathrm{NH}_{3}\right]_{\text {solution }} } & =\frac{[\mathrm{TAN}]}{1+\left(\left[\mathrm{H}_{3} \mathrm{O}^{+}\right] / K_{\mathrm{N}}\right)}
\end{aligned}
$$

where TAN is $\mathrm{NH}_{3}+\mathrm{NH}_{4}\left(\mu \mathrm{g} \mathrm{N} \mathrm{m}{ }^{-3}\right), K_{\mathrm{N}}$ is the equilibrium constant for $\mathrm{NH}_{4}$ dissociation, and $K_{\mathrm{H}}$ is Henry's law constant for the distribution between $\left[\mathrm{NH}_{3}\right]_{\text {solution }}$ and $\left[\mathrm{NH}_{3}\right]_{\mathrm{gas}}$. The relationships between these equilibrium constants and temperature $(T)$ in Kelvin $\left(\mathrm{K}=273+{ }^{\circ} \mathrm{C}\right)$ are:

$$
\begin{gathered}
\log K_{\mathrm{H}}=-1.69+1477.7 / T \\
\log K_{\mathrm{N}}=-0.09018-2729.92 / T
\end{gathered}
$$
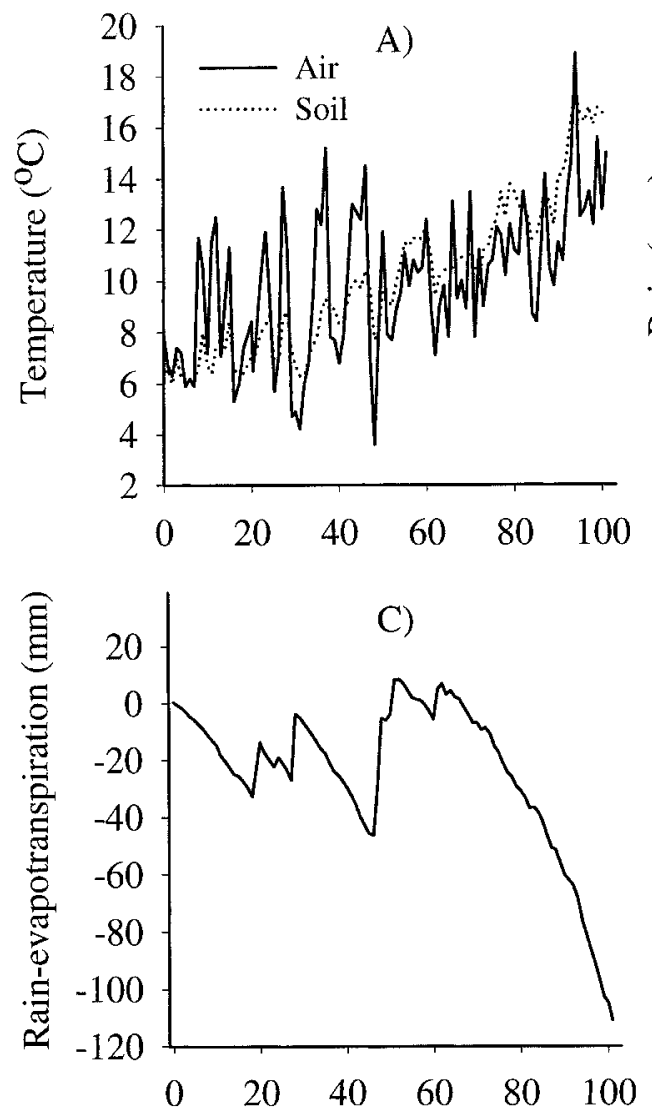

The effect of environment and soil composition on $\mathrm{N}_{2} \mathrm{O}$ emission was analyzed by means of linear regression analysis (Stepwise; SAS Institute, 1989).

\section{RESULTS}

\section{Manure and Climate}

The pig slurry used (Table 1) was similar in composition to slurries studied in Europe (Japenga and Harmsen, 1990; Sommer and Husted, 1995), but contained more dry matter and plant nutrients than the slurry employed in a previous experiment by Sommer and Sherlock (1996). Daily mean air temperature during the course of the study increased from 7 to $18^{\circ} \mathrm{C}$ with considerable fluctuations of up to $10^{\circ} \mathrm{C}$ between days (Fig. 1A). During the same period, the mean soil temperature at a $10-\mathrm{cm}$ depth increased from 6 to $17^{\circ} \mathrm{C}$, with fluctuations between days of approximately $2^{\circ} \mathrm{C}$. Little rain fell during the first $19 \mathrm{~d}$ (Fig. 1B), but the next $8 \mathrm{~d}$ were reasonably wet with $20 \mathrm{~mm}$ of rain on Day 20, $5 \mathrm{~mm}$ on Day 24, and $25 \mathrm{~mm}$ on Day 28. No rain fell between Days 29 and 46, but there were numerous rainfall events between Days 46 and 90 when between 0.5 and $25 \mathrm{~mm}$ rain fell per day (Fig. 1B). Pan evaporation was generally greater than rainfall (Fig. 1C), thus the soil dried between major rainfall events (Fig. 1D).
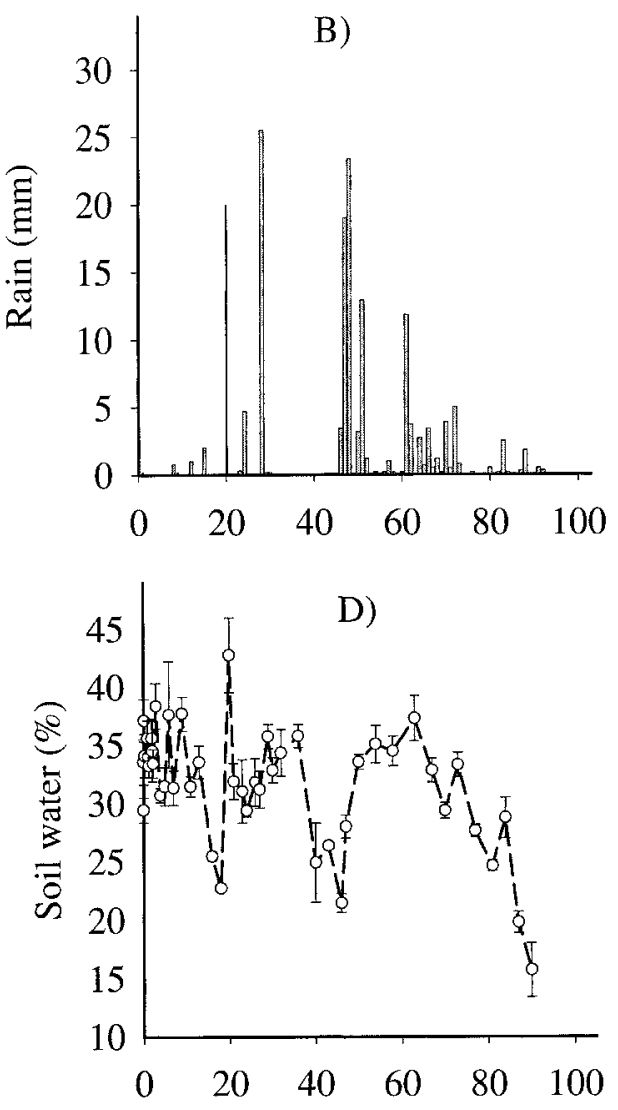

Time after slurry application (days)

Fig. 1. Daily mean soil temperature at $10 \mathrm{~cm}$ and air temperature $(A)$, rainfall $(B)$, rainfall - evapotranspiration $(C)$, and soil water content $(D)$ during the duration of the study. Error bars are \pm 1 SD. 
After $65 \mathrm{~d}$, the discrepancy between evaporation and rainfall increased markedly (Fig. 1C) and the soil moisture content fell to approximately $15 \%$ (Fig. 1D). The wind speed varied from 0.63 to $2.83 \mathrm{~m} \mathrm{~s}^{-1}$ during the first $3 \mathrm{~d}$ after slurry application.

\section{Soil Composition}

The surface soil $\mathrm{pH}$ increased from 6.3 to 8.1 immediately after slurry application. The $\mathrm{pH}$ then rose to 8.3 (probably due to the loss of carbon dioxide; Sommer and Sherlock, 1996), remained at that level for approximately $3 \mathrm{~d}$, and then decreased slowly to 7.7 on Day 16 (Fig. 2A). Immediately after application the $\mathrm{NH}_{4}-\mathrm{N}$
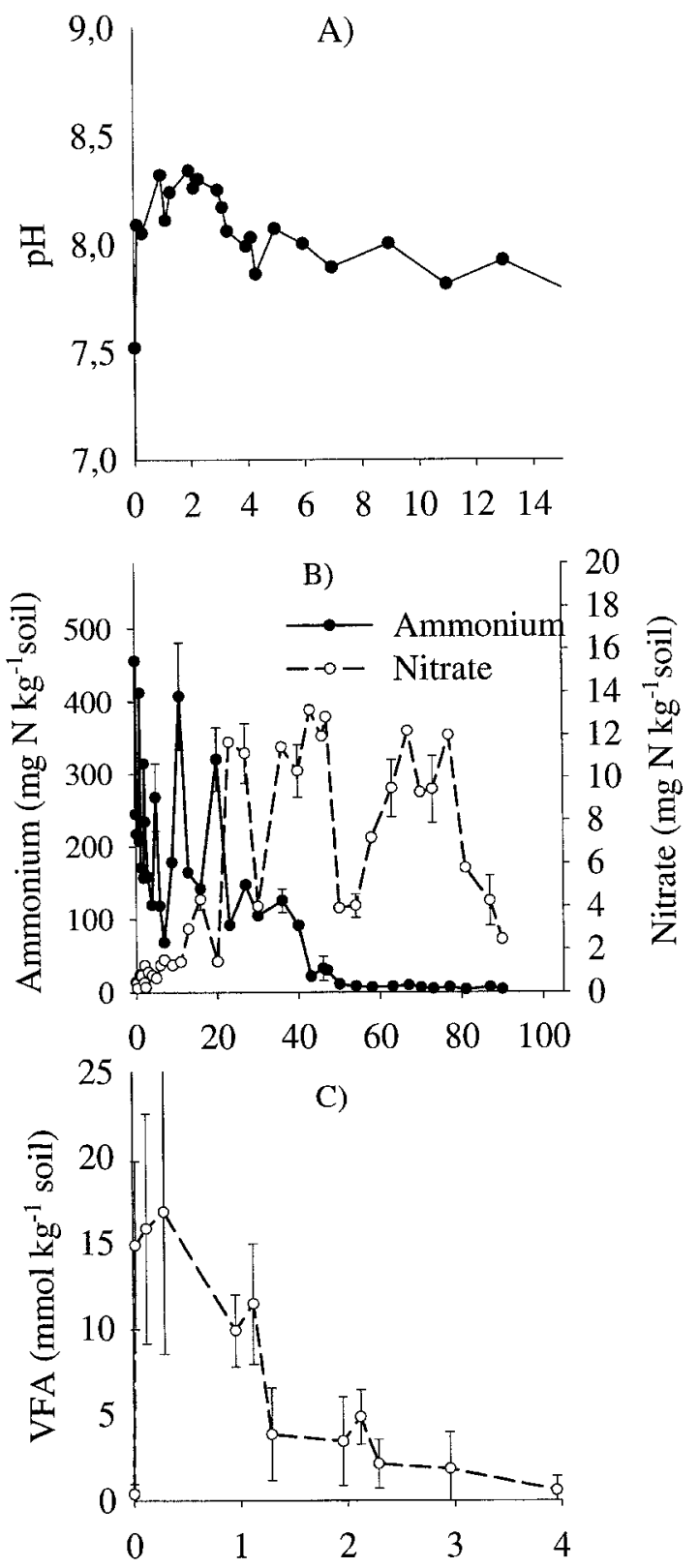

Time after slurry application (days)

Fig. 2. Changes in surface soil $\mathrm{pH}(A), \mathrm{NO}_{3}$ and $\mathrm{NH}_{4}$ concentrations $(B)$, and volatile fatty acids (VFA) $(C)$ in the pasture soil following slurry application. Error bars are \pm 1 SD. concentration in the 0 - to $5-\mathrm{cm}$ surface soil layer was approximately $460 \mathrm{mg} \mathrm{kg}^{-1}$ soil. The $\mathrm{NH}_{4}-\mathrm{N}$ concentration fluctuated between 400 and $60 \mathrm{mg} \mathrm{kg}^{-1}$ soil over the next $22 \mathrm{~d}$, remained around $100 \mathrm{mg} \mathrm{kg}^{-1}$ soil until Day 40, and then decreased to background levels on Day 52 (Fig. 2B).

The TAN concentration in the soil solution before slurry application was $20 \mathrm{mg} \mathrm{L}^{-1}$. When the slurry was applied, TAN in the soil solution at the surface was equal to that in the solution applied, $4200 \mathrm{mg} \mathrm{L}^{-1}$. This decreased to $1026 \mathrm{mg} \mathrm{L}^{-1} 3 \mathrm{~h}$ after slurry application and fluctuated around $713 \mathrm{mg} \mathrm{L}^{-1}$ for the next $2.5 \mathrm{~d}$. It declined to background values on Day 52 (Fig. 2B).

Pig slurry application decreased the $\mathrm{NO}_{3}$ concentration in the 0 - to 5 - $\mathrm{cm}$ soil layer from 2.9 to $0.2 \mathrm{mg} \mathrm{N} \mathrm{kg}^{-1}$ soil. There was little change in the $\mathrm{NO}_{3}$ concentration of the top $5 \mathrm{~cm}$ of soil until Day 10 when approximately $3 \mathrm{~mm}$ rain fell. After $20 \mathrm{~mm}$ rain fell on Day 20, the $\mathrm{NO}_{3}$ concentration in the surface soil decreased from 4 to $1.2 \mathrm{mg} \mathrm{N} \mathrm{kg}^{-1}$ soil and then increased rapidly to approximately $11.4 \mathrm{mg} \mathrm{N} \mathrm{kg}^{-1}$ soil (Fig. $1 \mathrm{~B}$ and $2 \mathrm{~B}$ ). The $\mathrm{NO}_{3}$ concentration fell again after rain on Days 30 and 50 and returned to approximately $12 \mathrm{mg} \mathrm{N} \mathrm{kg}^{-1}$ soil on each occasion. It finally decreased to the background value around Day 90 (Fig. 2B).

The concentration of volatile fatty acids in the soil solution declined from approximately $15 \mathrm{~m} M \mathrm{~kg}^{-1}$ soil just after slurry application to $4 \mathrm{~m} M \mathrm{~kg}^{-1}$ soil within $1.5 \mathrm{~d}$ (Fig. 2C). It then slowly decreased over the next $3 \mathrm{~d}$ to $0.8 \mathrm{mM} \mathrm{kg}{ }^{-1}$ soil, which was not significantly different from the background concentration of $0.6 \mathrm{mM}$ $\mathrm{kg}^{-1}$ soil.

\section{Ammonia Emission}

In the first 2.5-h period after slurry application, $\mathrm{NH}_{3}$ was lost at a rate of $4.7 \mathrm{~kg} \mathrm{~N} \mathrm{ha}^{-1} \mathrm{~h}^{-1}$. In the next 4-h period, $\mathrm{NH}_{3}$ was lost at about half the initial rate $(2.2 \mathrm{~kg}$ $\mathrm{N} \mathrm{ha}^{-1} \mathrm{~h}^{-1}$ ) and overnight the rate dropped to $0.26 \mathrm{~kg}$ $\mathrm{N} \mathrm{ha}^{-1} \mathrm{~h}^{-1}$ (Fig. 3A). After Day $1, \mathrm{NH}_{3}$ volatilization rates declined markedly to average daytime and nighttime rates over the next $2 \mathrm{~d}$ of 0.57 and $0.11 \mathrm{~kg} \mathrm{~N} \mathrm{ha}^{-1}$ $\mathrm{h}^{-1}$, respectively (Fig. 3A). Ammonia was lost at faster rates in the morning session (900-1300 h) than in the afternoon session (1300-1700 $\mathrm{h}$ ) and the overnight rates

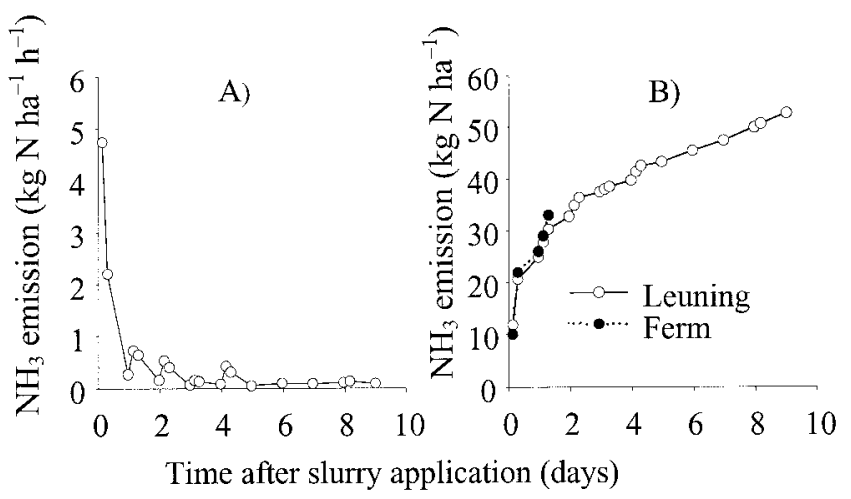

Fig. 3. Ammonia emission from the slurry amended area during the study $(A)$ and cumulative $\mathrm{NH}_{3}$ loss in Leuning samplers and Ferm tubes $(B)$. 
Table 2. Accumulated flux of gases from a pasture after pig slurry application in late winter and spring.

\begin{tabular}{|c|c|c|c|c|c|}
\hline & \multicolumn{2}{|c|}{ Emission during $12 \mathrm{~d}$ after slurry application } & \multicolumn{2}{|c|}{ Emission during the experiment } & \multirow{2}{*}{$\frac{\text { Net emission }}{\text { Slurry-amended plot }}$} \\
\hline & Slurry-amended plot & Untreated area & Slurry-amended plot & Untreated area & \\
\hline & & & g ha $\mathbf{a}^{-1}$ & & \\
\hline $\mathbf{N H}_{3}-\mathbf{N}$ & 57000 & 0 & 57000 & 0 & 57000 \\
\hline $\mathrm{CH}_{4}-\mathrm{C}$ & 1065 & $-26 \dagger$ & 858 & -194 & 1052 \\
\hline $\mathbf{N}_{2} \mathbf{O}-\mathbf{N}$ & 442 & 534 & 8134 & 534 & 7600 \\
\hline
\end{tabular}

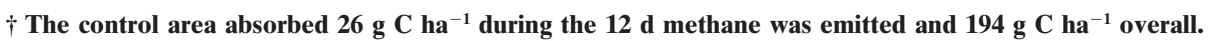

$\$$ The slurry-treated plot absorbed $207 \mathrm{~g} \mathrm{C} \mathrm{ha}^{-1}$ after methane emission ceased.

were always low (Fig. 3A). As a result of the fast rates of loss, $24.8 \mathrm{~kg} \mathrm{~N} \mathrm{ha}^{-1}$ was lost on Day 1 (Fig. 3B; equivalent to $6.8 \%$ of the applied $\mathrm{N}$ or $9.8 \%$ of the TAN). During the next two days, 7.8 and $4.8 \mathrm{~kg} \mathrm{~N}^{-1}$ were lost, and thereafter until Day $9, \mathrm{NH}_{3}$ was lost at the rate of approximately $2.5 \mathrm{~kg} \mathrm{~N} \mathrm{ha}{ }^{-1} \mathrm{~d}^{-1}$. Little $\mathrm{NH}_{3}$ was volatilized after Day 10. The total $\mathrm{NH}_{3}$ emission was $57 \mathrm{~kg} \mathrm{~N} \mathrm{ha}^{-1}$ (Table 2), corresponding to $15.5 \%$ of the total nitrogen applied to the field in pig slurry or $22.5 \%$ of its original TAN content. It can be seen from Fig. 3B that the results for $\mathrm{NH}_{3}$ loss obtained with the Ferm tubes (Schjoerring et al., 1992) were similar to those obtained with the passive samplers of Leuning et al. (1985).

As the slurry applied had a high TAN concentration $\left(4.2 \mathrm{~kg} \mathrm{~N} \mathrm{~m}^{-3}\right)$ and a high $\mathrm{pH}(8.14)$, the equilibrium $\mathrm{NH}_{3}$ concentration $\left(\left[\mathrm{NH}_{3}\right]_{\text {gas }}\right)$ at the beginning of the study was high. Its concentration decreased with time. The product of $\left[\mathrm{NH}_{3}\right]_{\text {gas }}$ and wind speed also decreased with time, and there was a very strong linear relationship between $\mathrm{NH}_{3}$ loss and this product:

$$
F=89 \times 10^{-4}\left[\mathrm{NH}_{3}\right]_{\text {gas }} \times u-19.95 ; r^{2}=0.9423
$$

\section{Methane}

Methane emission commenced at the very fast rate of $39.33 \mathrm{~g} \mathrm{C} \mathrm{ha}^{-1} \mathrm{~h}^{-1}$ immediately after pig slurry application and decreased to $10 \mathrm{~g} \mathrm{C} \mathrm{ha}^{-1} \mathrm{~h}^{-1}$ within $6 \mathrm{~h}$ (Fig. 4A). The $\mathrm{CH}_{4}$ emission rate then decreased, but emission continued at a lower rate for approximately $7 \mathrm{~d}$. Thereafter, $\mathrm{CH}_{4}$ flux measurements indicated net uptake of atmospheric $\mathrm{CH}_{4}$ by the treated plot (Table 2). The control plot absorbed $\mathrm{CH}_{4}$ from the atmosphere at the rate of $9.1 \mu \mathrm{g} \mathrm{C} \mathrm{m}{ }^{-2} \mathrm{~h}^{-1}$ throughout the study period.

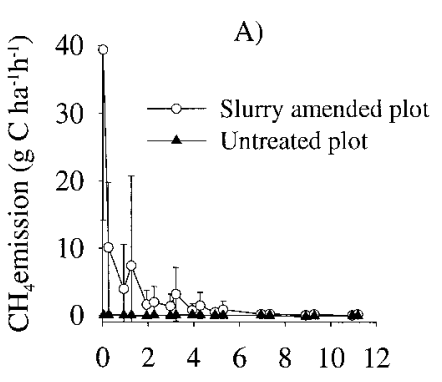

Time after slurry application (days)

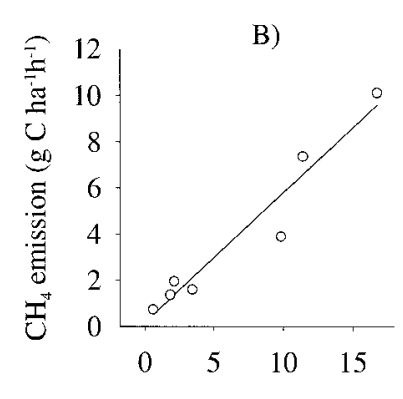

VFA (mmol kg-1 soil)
Fig. 4. Methane emission from the slurry amended area, and the control areas during the study $(A)$, and the relationship between $\mathrm{CH}_{4}$ emission and the volatile fatty acid concentration in the 0 - to 5cm surface layer of soil $(B)$. Error bars are \pm 1 SD.
Except for the first flux measurement, the $\mathrm{CH}_{4}$ flux $\left(F_{\mathrm{CH} 4}\right)$ from the slurry-amended plot was linearly related to the volatile fatty acids (VFA) concentration in the soil:

$$
F_{\mathrm{CH} 4}=0.170 \mathrm{VFA}+0.026 ; r^{2}=0.948
$$

during the period $2 \mathrm{~h}$ to $11 \mathrm{~d}$ after slurry application (Fig. 4B). The emission immediately after slurry application was considerably faster than that after $1 \mathrm{~h}$, which suggested that the first burst of $\mathrm{CH}_{4}$ gas originated from $\mathrm{CH}_{4}$ dissolved in the slurry. The regression between subsequent emissions and the disappearance of volatile fatty acids in the soil suggests that the subsequent $\mathrm{CH}_{4}$ was produced in the soil from organic matter supplied in the slurry. In the $12 \mathrm{~d}$ immediately following application, $1065(\mathrm{SE} \pm 425) \mathrm{g} \mathrm{CH}_{4}-\mathrm{C} \mathrm{ha}^{-1}$ was emitted from the slurry-amended plot, of which $26 \%$ was emitted within $1 \mathrm{~h}$ and $46 \%$ within $6 \mathrm{~h}$. The subsequent small net sink activity from the treated area over the following $78 \mathrm{~d}$ amounted to $207( \pm 16) \mathrm{g} \mathrm{CH}_{4}-\mathrm{Cha}^{-1}$. The net emission from the slurry-amended plot, therefore, was $858 \mathrm{~g}$ $\mathrm{CH}_{4}-\mathrm{C} \mathrm{ha}^{-1}$. During the experiment the control area absorbed $194 \mathrm{~g} \mathrm{CH}_{4}-\mathrm{C} \mathrm{ha}^{-1}$, consequently the net emission from the treated area was $1052 \mathrm{~g} \mathrm{CH}_{4}-\mathrm{C} \mathrm{ha}^{-1}$.

\section{Nitrous Oxide}

At all times emissions from the slurry-treated plot were significantly greater than those from the untreated control plots (approximately $0.08 \mathrm{~g} \mathrm{~N} \mathrm{ha}^{-1} \mathrm{~h}^{-1}$; Fig. 5). Nitrous oxide emissions from the slurry-amended plot were low $\left(1 \mathrm{~g} \mathrm{~N} \mathrm{ha}^{-1} \mathrm{~h}^{-1}\right)$ for the first $14 \mathrm{~d}$ after applica-

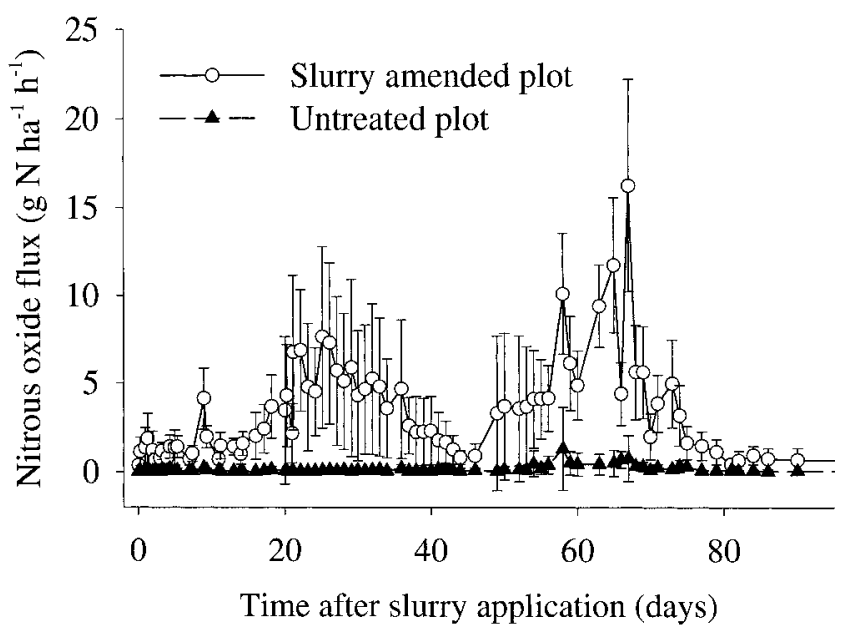

Fig. 5. Nitrous oxide emission from the slurry amended area and the control areas during the study. Error bars are \pm 1 SD. 
tion, when the $\mathrm{NO}_{3}$ concentration in the 0 - to $5-\mathrm{cm}$ surface soil layer was low. In the $11 \mathrm{~d}$ that followed, the $\mathrm{NO}_{3}$ concentration in the surface soil increased (Fig. 2B), and $\mathrm{N}_{2} \mathrm{O}$ emissions increased to a peak of $7.5 \mathrm{~g} \mathrm{~N}$ $\mathrm{ha}^{-1} \mathrm{~h}^{-1}$. The emissions then declined to approximately $1 \mathrm{~g} \mathrm{~N} \mathrm{ha}^{-1} \mathrm{~h}^{-1}$ after $20 \mathrm{~d}$ of rain-free weather (Fig. 1B). Nitrous oxide fluxes then increased in response to rain to create a second peak flux of $15.8 \mathrm{~g} \mathrm{~N} \mathrm{ha}^{-1} \mathrm{~h}^{-1}, 67 \mathrm{~d}$ after slurry application. The subsequent decline in daily $\mathrm{N}_{2} \mathrm{O}$ flux over the next $23 \mathrm{~d}$ to background values coincided with low rainfall and low mineral $\mathrm{N}$ in the soil layer (Fig. 1B and 2B).

\section{DISCUSSION}

\section{Loss Patterns}

Pig slurry consists of a mixture of urine, feces, used bedding, waste feed, and other residual organic matter. In stored slurry, urea (added in urine) is hydrolyzed, providing $\mathrm{NH}_{3}$ and alkalinity, $\mathrm{CH}_{4}$ is produced through the degradation of organic compounds under anaerobic conditions, and nitrification is inhibited (Husted, 1994). The composition of the pig slurry manure applied in this study is similar to the composition of manures analyzed in Europe (Sommer and Hutchings, 2001).

The fastest rate of $\mathrm{NH}_{3}$ loss occurred immediately after application, and the loss rate then decreased quickly with time (Fig. 3A). In contrast, when urea or urine is added to the soil surface, little $\mathrm{NH}_{3}$ is lost initially and the maximum rate of loss does not occur until two or three days after application, and thereafter the loss rates decline slowly (Sherlock et al., 1995). The differing patterns at the beginning seem to be due to the composition of the material added. With fertilizer or urine, urea has to be hydrolyzed to produce $\mathrm{NH}_{3}$ and a source of alkalinity before any loss could occur, whereas the slurry contained a high TAN concentration and had a high $\mathrm{pH}$, and thus $\mathrm{NH}_{3}$ could be lost immediately.

As noted above (Eq. [11]), a very strong relationship was found between the vertical flux density of $\mathrm{NH}_{3}$ and the product of $\left[\mathrm{NH}_{3}\right]_{\text {gas }}$ and wind speed, following pig slurry application to a pasture soil. In studies on $\mathrm{NH}_{3}$ losses following urea and urine application to unsaturated soils (Sherlock et al., 1995) the coefficients of inclination (slopes) of the comparable relationships were $0.69 \times 10^{-4}$ after urea application and $0.9 \times 10^{-4}$ after urine application. The slope in this current study was higher due to the different approach used to sample the soil, that is, in the study of Sherlock et al. (1995) soil was sampled by scraping off the top few millimeters of the soil surface, while in this current study soil samples were taken from the $0-$ to $5-\mathrm{cm}$ depth. The TAN concentration will be lower when taking a $0-$ to $5-\mathrm{cm}$ sample than in a sample from the topsoil of slurryor urea-amended soil, and therefore the $\left[\mathrm{NH}_{3}\right]_{\text {gas }} \times u$ product is lower.

The reasons for the low $\mathrm{NH}_{3}$ emission rates after the initial fast rate are uncertain. In the case of urea or urine the slow decline in loss rates may be due to acidifi- cation of the soil surface as a result of $\mathrm{NH}_{3}$ loss, leaching of urea below the soil surface by rainfall, oxidation by nitrifying organisms, reaction with the cation exchange complex, immobilization, and uptake by plants. While many of these factors would have operated to reduce $\mathrm{NH}_{3}$ loss after slurry application, none of them seems to be responsible for the rapid decline in $\mathrm{NH}_{3}$ loss rates on Day 1 . The $\mathrm{pH}$ of the surface soil actually increased slightly during the first $3 \mathrm{~d}$ (Fig. 2A), there was little rainfall to leach the slurry into the soil during the first $20 \mathrm{~d}$ (Fig. 1B), and little $\mathrm{NO}_{3}$ was produced until after Day 20. The soil has considerable cation exchange capacity $\left(15.4 \mathrm{cmol}\left[\mathrm{Na}^{+}\right] \mathrm{kg}^{-1}\right)$, and $\mathrm{NH}_{4}$ would be adsorbed on the cation exchange complex in the surface soil as the slurry infiltrated. Immobilization would be expected to occur, especially as organic carbon was added in the slurry (Comfort et al., 1988; Kirchmann and Lundvall, 1993), but considerable $\mathrm{NH}_{4}$ remained in the soil until Day 40, and only $22.5 \%$ of the TAN was lost as $\mathrm{NH}_{3}$. Nitrogen uptake by plants should have been slow and small because the surface cover was small and growth slow because of the low soil and air temperatures. However, Thompson et al. (1990) studied $\mathrm{NH}_{3}$ loss from slurries in the absence of soil and concluded that the decline in $\mathrm{NH}_{3}$ loss rates was due to the formation of a crust on the slurry surface. With time, the crust becomes thicker and the slurry more viscous, thereby increasing resistances to diffusion within the slurry. The TAN in the crust surface can then become depleted due to $\mathrm{NH}_{3}$ volatilization (Sommer and Olesen, 2000).

The changes in the physical nature of the slurry would also restrict oxygen diffusion and ensure that the slurry remained anaerobic for up to $20 \mathrm{~d}$, thus allowing $\mathrm{CH}_{4}$ formation in situ, and limiting $\mathrm{NH}_{4}$ nitrification (Fig. 2B). The addition of carbon in the slurry would stimulate microbial activity in the soil, rapidly consume any available oxygen present (Firestone, 1982), and guarantee that the slurry-treated surface soil remained anaerobic. The $\mathrm{CH}_{4}$ emission from the treated pasture at a rate of $39.6 \mathrm{~g} \mathrm{C} \mathrm{ha}^{-1} \mathrm{~h}^{-1}$ immediately after slurry application indicates that this $\mathrm{CH}_{4}$ was formed in the slurry pit prior to application, as there would not have been sufficient time for its formation in soil (Fig. 4A). It is noteworthy that this initial peak $\mathrm{CH}_{4}$ emission is not high in relation to the likely $\mathrm{CO}_{2}$ emissions. For example, Dendooven et al. (1998) measured average $\mathrm{CO}_{2}$ emission rates of $23 \mathrm{~kg} \mathrm{CO}-\mathrm{C} \mathrm{ha}^{-1} \mathrm{~d}^{-1}$ (960 $\mathrm{g} \mathrm{CO}_{2}-\mathrm{C} \mathrm{ha}^{-1} \mathrm{~h}^{-1}$ ) during the $28 \mathrm{~d}$ following pig slurry application $\left(40000 \mathrm{~kg} \mathrm{ha}^{-1}\right)$ to a bare soil. Further, small amounts of $\mathrm{CH}_{4}$ originating from this initial source may have diffused out from the viscous layer over the next few hours. However, the strong correlation between $\mathrm{CH}_{4}$ emission and volatile fatty acids (Fig. 4B) suggests that the $\mathrm{CH}_{4}$ emissions over the next $7 \mathrm{~d}$ were more likely to have arisen in the anaerobic soil layer from the metabolism of volatile fatty acids supplied in the slurry. The duration of $\mathrm{CH}_{4}$ emission was longer than that observed previously (Sommer et al., 1996). The low temperatures may have caused this during the experiment, as it is known that $\mathrm{CH}_{4}$ production is strongly related to temperature (Zeikus and Winfrey, 1976). 
Table 3. Linear regression analysis (stepwise procedure) of nitrous oxide $\left(\mathrm{N}_{2} \mathrm{O}\right)$ emission $\left(\mathrm{g} \mathrm{N} \mathrm{ha} \mathbf{~ h}^{-1} \mathrm{~d}^{-1}\right)$ from a pasture amended with pig slurry (1-90 d). The full model is significant $(P<0.0001$, df $=30)$ with an $R^{2}$ of 0.6727 .

\begin{tabular}{|c|c|c|c|c|c|c|}
\hline Variable $\dagger$ & df & Estimate & Standard error & $T$ for $\mathbf{H}_{0}$ & $P>|T|$ & Partial $r^{2}$ \\
\hline Intercept & 1 & -74.7828 & 49.42681 & -1.5 & 0.143 & \\
\hline (0) Nitrate & 1 & 4.7094 & 3.0291 & 1.55 & $\mathbf{0 . 1 3 3 1}$ & 0.1942 \\
\hline (0) Rain* & $\mathbf{1}$ & -22.21939 & 9.80682 & -2.27 & 0.0328 & 0.0631 \\
\hline (1) Rain** & 1 & $\mathbf{5 . 7 8 5 1 7}$ & 1.88698 & 3.07 & 0.0053 & 0.0450 \\
\hline (1) Air temperature* & 1 & 12.69788 & 5.36952 & 2.36 & 0.0265 & 0.0573 \\
\hline (0) Incident solar radiation** & $\mathbf{1}$ & 5.97654 & 2.19186 & 2.73 & 0.0118 & 0.0505 \\
\hline$\sum$ (Rain - evaporation) $* * *$ & 1 & 4.39803 & 0.76016 & 5.79 & $<\mathbf{0 . 0 0 0 1}$ & 0.2556 \\
\hline
\end{tabular}

* Significant at the 0.05 probability level.

** Significant at the 0.01 probability level.

**** Significant at the 0.001 probability level.

$\dagger$ The number before the variable denotes whether the variable pertains to the day of flux measurements (0) or the day before (1).

As discussed above, slurry addition appeared to restrict oxygen diffusion and the surface soil remained anaerobic for a lengthy period. While this limited nitrification for the first $14 \mathrm{~d}$ after application, it did not completely prevent it, as some $\mathrm{NO}_{3}$ was formed (Fig. 2B) and some $\mathrm{N}_{2} \mathrm{O}$ was emitted (Fig. 5). The likely sequence of reactions responsible for the small $\mathrm{NO}_{3}$ and $\mathrm{N}_{2} \mathrm{O}$ production seems to be the same as those operating in flooded soils, namely (i) $\mathrm{NH}_{4}$ in the slurry diffused to a zone in the soil containing residual oxygen, (ii) this $\mathrm{NH}_{4}$ was oxidized to $\mathrm{NO}_{3}$ by nitrifying organisms, (iii) the $\mathrm{NO}_{3}$ formed diffused back to the anaerobic zone, (iv) denitrification occurred with $\mathrm{N}_{2} \mathrm{O}$ and $\mathrm{N}_{2}$ production, and (v) the gaseous products diffused through the anaerobic layer to the atmosphere. During the diffusion through the anaerobic layer, $\mathrm{N}_{2} \mathrm{O}$ may have been further reduced to $\mathrm{N}_{2}$, resulting in little $\mathrm{N}_{2} \mathrm{O}$ emission (Patrick, 1982; Petersen et al., 1992).

The initial peak in $\mathrm{N}_{2} \mathrm{O}$ emission occurred during a period of active nitrification (Fig. 2B) and may have resulted from nitrification as well as by denitrification of the resulting $\mathrm{NO}_{3}$ (Jarvis et al., 1994; Lessard et al., 1996). However, the second peak occurred when $\mathrm{NH}_{4}$ concentrations were low (Fig. $2 \mathrm{~B}$ ), and $\mathrm{NO}_{3}$ concentrations (Fig. 2B) and soil moisture contents (Fig. 1D) were high, and thus appears to be mainly the result of denitrification. Lessard et al. (1996) have shown that both nitrification and denitrification may be sources of $\mathrm{N}_{2} \mathrm{O}$ within soils amended with manure $\mathrm{N}$ but that the relative contribution of the two processes could not be quantified. In this study the pool of $\mathrm{NH}_{4}$ was significantly higher than the $\mathrm{NO}_{3}$ pool during 0 to approximately $30 \mathrm{~d}$ after slurry application (Fig. 2B). Consequently, $\mathrm{NH}_{4}$ oxidation may have been the most prominent source of $\mathrm{N}_{2} \mathrm{O}$ emission in this period (Jarvis et al., 1994). After $30 \mathrm{~d}$ the $\mathrm{NH}_{4}$ pool was nearly depleted while the pool of $\mathrm{NO}_{3}$ was significantly higher. Thus, $\mathrm{NO}_{3}$ may have been the major $\mathrm{N}_{2} \mathrm{O}$ source from $30 \mathrm{~d}$ until the conclusion of the experiment at $90 \mathrm{~d}$.

The $\mathrm{N}_{2} \mathrm{O}$ emission was slightly greater at 1600 than at $1000 \mathrm{~h}$ during days when emissions were measured twice daily, indicating a diurnal variation. Therefore, estimates of accumulated $\mathrm{N}_{2} \mathrm{O}$ emissions may be influenced by the sampling times selected, for example, estimated emissions would be higher from measurements performed at 1600 than at $1000 \mathrm{~h}$ (Brumme and Beese, 1992; Granli and Bøckman, 1994; Thornton et al., 1996). The diurnal variation was largely related to warming of soil during the day. We therefore assumed that $\mathrm{N}_{2} \mathrm{O}$ fluxes measured around noon would represent the average diurnal flux, and statistical analysis was performed with $\mathrm{N}_{2} \mathrm{O}$ emission rates and average daily climate data. Nitrous oxide emission was correlated $(P<0.15 \%)$ to the $\mathrm{NO}_{3}$ concentration in the topsoil (Table 3), confirming that most of the $\mathrm{N}_{2} \mathrm{O}$ emitted originated from $\mathrm{NO}_{3}$. Cumulative net precipitation and rain the day before a measurement had a significant positive effect on $\mathrm{N}_{2} \mathrm{O}$ fluxes $(P<0.01)$. This is consistent with stimulation of $\mathrm{NO}_{3}$ denitrification due to water saturation, which induces anoxic conditions in the soil. Rain on the day of measurement had a negative significant effect $(P<$ 0.05 ) on $\mathrm{N}_{2} \mathrm{O}$ emission. Rain causes an immediate increase in soil water content to above field capacity in the topsoil and air-filled porosity will be very low under this condition. Consequently, $\mathrm{N}_{2} \mathrm{O}$ gas has to be transported by slow diffusion through water instead of a faster combination of diffusion and convection in soil air. This change in transport mechanism reduces the $\mathrm{N}_{2} \mathrm{O}$ flux until the soil water is again less than or equal to field capacity. Air temperature and incident solar radiation has a positive significant effect on $\mathrm{N}_{2} \mathrm{O}$ emission (Table 3). The increase with air temperature and incident solar radiation may be due to a reduced solubility of $\mathrm{N}_{2} \mathrm{O}$ in soil solution at increasing temperatures or an increase in $\mathrm{N}_{2} \mathrm{O}$ production with temperature (Müller et al., 1997).

\section{Amounts Lost}

The ammonia amounts lost from pig slurry in this study were within the range found in other studies (e.g., Bless et al., 1991; Moal et al., 1995; Sommer and Olesen, 2000 ) where losses of up to $67 \%$ of TAN contained in the slurry were reported. The relatively low loss in the current study ( $22.5 \%$ of the TAN) is most likely due to the lower air and soil temperatures.

It is considered that animal slurries applied to soil do not constitute an important source of $\mathrm{CH}_{4}$ (Intergovernmental Panel on Climate Change, 1996), but very few studies appear to have been made on the amounts lost from pig slurry after surface application to field soils. Chadwick and Pain (1997) investigated the effect of soil and slurry type on $\mathrm{CH}_{4}$ emissions under laboratory conditions and showed that most of the $\mathrm{CH}_{4}$ emitted was derived from the slurry, that emissions declined to background levels after $48 \mathrm{~h}$, and that more $\mathrm{CH}_{4}$ was 
emitted from pig slurry than cattle slurry when applied to a clay soil. In another laboratory study, Sommer et al. (1996) found that $30 \mathrm{~g}$ were emitted from a silt loam after applying the equivalent of $50000 \mathrm{~kg}$ slurry per hectare. In that study the bulk of the $\mathrm{CH}_{4}(90 \%)$ was emitted within $4 \mathrm{~h}$ of slurry application. In the current study, the net $\mathrm{CH}_{4}$ emission was $0.07 \%$ of the carbon applied, and $46 \%$ of the total was lost within $6 \mathrm{~h}$.

Simple integration and extrapolation of the daily emissions gives a total emission of $7.6 \mathrm{~kg} \mathrm{~N}_{2} \mathrm{O}-\mathrm{N}$ ha $^{-1}$ during the course of this study $(2.1 \%$ of slurry $\mathrm{N}$ applied). Petersen (1999) reported accumulated $\mathrm{N}_{2} \mathrm{O}$ emissions between 0.14 and $0.64 \%$ of total $\mathrm{N}$ during a period of 6 to 8 weeks between slurry application and when crop uptake had depleted the inorganic $\mathrm{N}$ pools in the soil. Higher emissions reported in this study may be due to lower crop uptake of the mineral $\mathrm{N}$ applied in the manure. Based on data from long-term experiments with a variety of mineral and organic fertilizers, Mosier et al. (1998) recommend that only one factor should be used for calculating the $\mathrm{N}_{2} \mathrm{O}$ emission from different fertilizer types:

$$
\mathrm{N}_{2} \mathrm{O} \text { emitted }=1.25 \% \text { of } \mathrm{N} \text { applied }\left(\mathrm{kg} \mathrm{N} \mathrm{ha}^{-1}\right)
$$

although it is acknowledged that more data are required before final emission factors can be allocated. The results of our study may assist in assigning a suitable factor for calculating $\mathrm{N}_{2} \mathrm{O}$ emission following animal slurry application to agricultural land. In the current study, $\mathrm{N}_{2} \mathrm{O}$ emission was $2.1 \%$ of the total $\mathrm{N}$ applied in the slurry, which is much greater than the emission factor proposed for inorganic and organic fertilizers.

\section{Interactions}

Aerobic soils constitute one of the most important sinks for atmospheric $\mathrm{CH}_{4}$ (Intergovernmental Panel on Climate Change, 1996). However, the capacity of soils to absorb $\mathrm{CH}_{4}$ and oxidize it to $\mathrm{CO}_{2}$ (Knowles, 1993) is reduced by agricultural practices that affect $\mathrm{N}$ cycling. This occurs because of the close relationships between pathways for $\mathrm{NH}_{3}$ and $\mathrm{CH}_{4}$ oxidation (Steudler et al., 1989; Mosier et al., 1991). There have been a number of studies on the effects of fertilizer $\mathrm{N}$ and cultivation on $\mathrm{CH}_{4}$ uptake, and the effect is greater in some soils than in others and in general $\mathrm{NH}_{4}$ addition has a greater effect than $\mathrm{NO}_{3}$ addition (e.g., Adamsen and King, 1993; Delgardo et al., 1996; Hütsch et al., 1994; Mosier et al., 1991, 1997; Willison et al., 1995). However, there have been few studies on the effect of slurry application on $\mathrm{CH}_{4}$ uptake (e.g., Hansen et al., 1993).

Two effects would be expected, a direct effect of the TAN from the slurry on the treated area and an indirect effect due to deposition of volatilized $\mathrm{NH}_{3}$ on the surrounding countryside. When $\mathrm{NH}_{3}$ is emitted into the atmosphere, some is absorbed by vegetation, some is dissolved in atmospheric water, converted to aerosols, and transported long distances $(1000+\mathrm{km})$, and some is deposited nearby (Ferm, 1998). Model estimates indicate that about $50 \%$ of the emitted $\mathrm{NH}_{3}$ is deposited on land or water surfaces within $50 \mathrm{~km}$ of the source
(Ferm, 1998). When $\mathrm{NH}_{3}$ or $\mathrm{NH}_{4}$ is deposited back onto soil the capacity of the soil to take up atmospheric $\mathrm{CH}_{4}$ may be affected.

After $12 \mathrm{~d}$ when $\mathrm{CH}_{4}$ contained in the slurry had been emitted and production in the soil had ceased, atmospheric $\mathrm{CH}_{4}$ was absorbed by the treated area. During the next $78 \mathrm{~d}, 207(\mathrm{SE} \pm 16) \mathrm{g} \mathrm{CH}_{4}-\mathrm{C} \mathrm{ha}^{-1}(9.7 \mu \mathrm{g} \mathrm{C}$ $\mathrm{m}^{-2} \mathrm{~h}^{-1}$ ) were absorbed by the treated area. Thus, the slurry treatment did not reduce the capacity of the soil to absorb $\mathrm{CH}_{4}$. In the control plots, $\mathrm{CH}_{4}$ absorption during the same time period amounted to $194(\mathrm{SE} \pm 9) \mathrm{g}$ $\mathrm{CH}_{4}-\mathrm{C} \mathrm{ha}^{-1}\left(9.1 \mu \mathrm{g} \mathrm{C} \mathrm{m}{ }^{-2} \mathrm{~h}^{-1}\right)$. Thus, the addition of the slurry had essentially no effect on $\mathrm{CH}_{4}$ uptake. The $\mathrm{CH}_{4}$ uptake in the slurry-treated area was similar to that on the unfertilized area of Hansen et al. (1993) in Norway $\left(9.7 \mu \mathrm{g} \mathrm{C} \mathrm{m}^{-2} \mathrm{~h}^{-1}\right)$ and almost twice that in the area they had treated with cattle slurry $(5.9 \mu \mathrm{g} \mathrm{C}$ $\left.\mathrm{m}^{-2} \mathrm{~h}^{-1}\right)$.

Total ammoniacal nitrogen added in the slurry would be expected to contribute to the burden of $\mathrm{N}_{2} \mathrm{O}$ in the atmosphere in two ways, directly by nitrification and denitrification on the treated area, and indirectly by metabolism of deposited $\mathrm{NH}_{3}$ on the surrounding countryside (Mosier et al., 1998). As noted above, the direct emission was $7.6 \mathrm{~kg} \mathrm{~N} \mathrm{ha}^{-1}$, and the indirect effect is $0.6 \mathrm{~kg} \mathrm{~N} \mathrm{ha}^{-1}$ (calculated from the emission factor proposed by Intergovernmental Panel on Climate Change [1997] and Mosier et al. [1998], namely 0.01 times the amount of $\mathrm{NH}_{3}$ emitted, $57 \mathrm{~kg} \mathrm{~N}^{-1}$ ), giving a total of $8.2 \mathrm{~kg} \mathrm{~N}_{2} \mathrm{O}-\mathrm{N} \mathrm{ha}{ }^{-1}$

\section{CONCLUSIONS}

This work has clearly shown that, of the two major greenhouse gases measured following the slurry application, $\mathrm{N}_{2} \mathrm{O}$ is by far the more important tropospheric pollutant. The quantity of $\mathrm{N}_{2} \mathrm{O}$ emitted was more than seven times that of the $\mathrm{CH}_{4}$. Furthermore, when scaled according to their global warming potentials and expressed in $\mathrm{CO}_{2}$ equivalents, the $\mathrm{N}_{2} \mathrm{O}$ emission equates to $3700 \mathrm{~kg} \mathrm{CO}$ while the $\mathrm{CH}_{4}$ emitted equates to only $29 \mathrm{~kg} \mathrm{CO}_{2}$. This direct comparison does not include the indirect $\mathrm{N}_{2} \mathrm{O}$ emissions from the volatilized $\mathrm{NH}_{3}$ that has been deposited on land or water bodies. The current IPCC default emission factor for $\mathrm{N}_{2} \mathrm{O}$ released from volatilized $\mathrm{NH}_{3}$ after deposition is 0.01 (Intergovernmental Panel on Climate Change, 1997). Thus, the $\mathrm{N}_{2} \mathrm{O}$ from that additional source could be expected to contribute a further $277 \mathrm{~kg}$ of $\mathrm{CO}_{2}$ equivalents as a consequence of this slurry application.

\section{ACKNOWLEDGMENTS}

We are grateful to Neil Smith, Trevor Hendry, and Stephen Moore for their expert technical assistance during the initial stages of the field experiment. The work carried out by S.G. Sommer was supported financially by the Danish Ministry of Food, Agriculture and Fishery (Sustainable Agriculture Research Programme).

\section{REFERENCES}

Adamsen, A.P.S., and G.M. King. 1993. Methane consumption in temperate and sub-arctic forest soils-Rates, vertical zonation, and 
responses to water and nitrogen. Appl. Environ. Microbiol. 59: 485-490.

Black, A.S., R.R. Sherlock, K.C. Cameron, N.P. Smith, and K.M. Goh. 1985. Comparison of three methods for measuring ammonia volatilization from urea granules broadcast on to pasture. J. Soil Sci. 36:271-280.

Bless, H.-G., R. Beinhauer, and B. Sattelmacher. 1991. Ammonia emission from slurry applied to wheat stubble and rape in North Germany. J. Agric. Sci. 117:225-231.

Bouwman, A.F., and H. Booij. 1998. Global use and trade of foodstuffs and consequences for the nitrogen cycle. Nutr. Cycling Agroecosyst. 52:261-267.

Brumme, R., and F. Beese. 1992. Effects of liming and nitrogenfertilization on emissions of $\mathrm{CO}_{2}$ and $\mathrm{N}_{2} \mathrm{O}$ from a temperate forest. J. Geophys. Res. 97:12851-12858.

Burton, C.H. 1997. Manure management-Treatment strategies for sustainable agriculture. Silsoe Research Institute, Silsoe, UK. J. Geophys. Res. 97:12851-12858.

Chadwick, D.R., and B.F. Pain. 1997. Methane fluxes following slurry applications to grassland soils: Laboratory experiments. Agric. Ecosyst. Environ. 63:51-60.

Comfort, S.D., K.A. Kelling, D.R. Keeney, and J.C. Converse. 1988. The fate of nitrogen from injected liquid manure in a silt loam soil. J. Environ. Qual. 17:317-322.

De Datta, S.K., A.C.F. Trevitt, J.R. Freney, W.N. Obcemea, J.G. Real, and J.R. Simpson. 1989. Measuring nitrogen losses from lowland rice using bulk aerodynamic and nitrogen- 15 balance methods. Soil Sci. Soc. Am. J. 53:1275-1281.

Delgardo, J.A., A.R. Mosier, R.H. Follett, R.F. Follett, D.G. Westfall, L.K. Klemedtsson, and J. Vermeulen. 1996. Effects of N management on $\mathrm{N}_{2} \mathrm{O}$ and $\mathrm{CH}_{4}$ fluxes and ${ }^{15} \mathrm{~N}$ recovery in an irrigated mountain meadow. Nutr. Cycling Agroecosyst. 46:127-134.

Dendooven, L., E. Bonhjomme, and R. Merckx. 1998. N dynamics and sources of $\mathrm{N}_{2} \mathrm{O}$ production following pig slurry application to a loamy soil. Biol. Fertil. Soils 26:224-228.

Denmead, O.T. 1983. Micrometeorological methods for measuring gaseous losses of nitrogen in the field. p. 133-157. In J.R. Freney and J.R. Simpson (ed). Gaseous loss of nitrogen from plant-soil systems. Martinus Nijhoff/Dr W Junk Publishers, The Hague, the Netherlands.

Denmead, O.T., J.R. Freney, and J.R. Simpson. 1982. Dynamics of ammonia volatilization during furrow irrigation of maize. Soil Sci. Soc. Am. J. 46:149-155.

Denmead, O.T., J.R. Simpson, and J.R. Freney. 1974. Ammonia flux into the atmosphere from a grazed pasture. Science 185:609-610.

Emerson, K., R.C. Russo, R.E. Lund, and R.V. Thurston. 1975. Aqueous ammonia equilibrium calculations: Effect of $\mathrm{pH}$ and temperature. J. Fish. Res. Board Can. 32:2379-2383.

European Centre for Ecotoxicology and Toxicology of Chemicals. 1994. Ammonia emissions to air in Western Europe. Tech. Rep. 62. ECETOC, Brussels.

FAOSTAT. 1999. Agricultural data on world wide web. Available online at http://apps.fao.org (verified 16 Apr. 2002). FAO, Rome

Ferm, M. 1998. Atmospheric ammonia and ammonium transport in Europe and critical loads-A review. Nutr. Cycling Agroecosyst. 51:5-17.

Firestone, M.K. 1982. Biological denitrification. p. 289-326. In F.J. Stevenson (ed.) Nitrogen in agricultural soils. ASA, CSSA, and SSSA, Madison, WI.

Fowler, D., U. Skiba, and K.J. Hargreaves. 1997. Emission of nitrous oxide from grasslands. p. 147-164. In S.C. Jarvis and B.F. Pain (ed.) Gaseous nitrogen emissions from grasslands. CAB Int., Wallingford, UK.

Freney, J.R., R. Leuning, J.R. Simpson, O.T. Denmead, and W.A. Muirhead. 1985. Estimating ammonia volatilization from flooded rice fields by simplified techniques. Soil Sci. Soc. Am. J. 49:1049-1054.

Freney, J.R., J.R. Simpson, and O.T. Denmead. 1983. Volatilization of ammonia. p. 1-32. In J.R. Freney and J.R. Simpson (ed.) Gaseous loss of nitrogen from plant-soil systems. Martinus Nijhoff/Dr W Junk Publishers, The Hague, the Netherlands.

Granli, T., and O.C. Bøckman. 1994. Nitrous oxide from agriculture. Norwegian J. Agric. Sci. Suppl. 12:128.

Hales, J.M., and D.R. Drewes. 1979. Solubility of ammonia in water at low concentrations. Atmos. Environ. 13:1133-1147.
Hansen, S., J.E. Maehlum, and L.R. Bakken. 1993. $\mathrm{N}_{2} \mathrm{O}$ and $\mathrm{CH}_{4}$ fluxes in soil influenced by fertilization and tractor traffic. Soil Biol. Biochem. 25:621-630.

Husted, S. 1994. Seasonal-variation in methane emission from stored slurry and solid manures. J. Environ. Qual. 23:585-592.

Hutchinson, G.L., and A.R. Mosier. 1981. Improved soil cover method for field measurement of nitrous oxide fluxes. Soil. Sci. Soc. Am. J. 45:311-316.

Hütsch, B.W., C.P. Webster, and D.S. Powlson. 1994. Methane oxidation in soil as affected by land-use, soil-pH and $\mathrm{N}$-fertilization. Soil Biol. Biochem. 26:1613-1622.

Intergovernmental Panel on Climate Change. 1996. Climate Change 1995. Impacts, adaptations and mitigation of climate change: Scientific-technical Analyses. Cambridge Univ. Press.

Intergovernmental Panel on Climate Change. 1997. Agriculture. p. 4.1-4.115. In Guidelines for national greenhouse gas inventories. Organization for Economic Cooperation and Development, Paris.

Japenga, J., and K. Harmsen. 1990. Determination of mass balances and ionic balances in animal manure. Neth. J. Agric. Sci. 38:353-367.

Jarvis, S.C., D.J. Hatch, B.F. Pain, and J.V. Klarenbeek. 1994. Denitrification and the evolution of nitrous oxide after the application of cattle slurry to a peat soil. Plant Soil 166:231-241.

Ke, B. 1998. Area-wide integration of crop and livestock: Case studyBeijing. p. 8-13. In Y.W. Ho and Y.K. Chan (ed.) Regional workshop on area wide-integration of crop-livestock activities. FAO Regional Office for Asia and Pacific (RAP), Bangkok, Thailand.

Kear, B.S., H.S. Gibbs, and R.B. Miller. 1967. Soils of the downs and plains of Canterbury and North Otago New Zealand. Soil Bureau Bull. 14. Dep. of Sci. and Ind. Res., Lower Hutt, New Zealand.

Keeney, D.R., and D.W. Nelson. 1982. Nitrogen-Inorganic forms. p. 643-693. In A.L. Page et al. (ed.) Methods of soil analysis. Part 2. 2nd ed. Agron. Monogr. 9. ASA and SSSA, Madison, WI.

Kirchmann, H., and A. Lundvall. 1993. Relationship between N immobilization and volatile fatty acids in soil after application of pig and cattle slurry. Biol. Fertil. Soils 15:161-164.

Knowles, R. 1993. Methane: Processes of production and consumption. p. 145-156. In L.A. Harper et al. (ed.) Agricultural ecosystem effects on trace gases and global climate change. ASA Spec. Publ 55. ASA, Madison, WI.

Lessard, R., P. Rochette, E.G. Gregorich, E. Pattey, and R.L. Desjardins. 1996. Nitrous oxide fluxes from manure-amended soil under maize. J. Environ. Qual. 25:1371-1377.

Leuning, R., J.R. Freney, O.T. Denmead, and J.R. Simpson. 1985. A sampler for measuring atmospheric ammonia flux. Atmos. Environ. 19:1117-1124.

Liss, P.S., and P.G. Slater. 1974. Flux of gases across the air-sea interface. Nature 247:181-184.

Moal, J.F., J. Martinez, F. Guiziou, and C.M. Coste. 1995. Ammonia volatilization following surface-applied pig and cattle slurry in France. J. Agric. Sci. 125:245-252.

Mosier, A.R., J.A. Delgado, V.L. Cochran, D.W. Valentine, and W.J. Parton. 1997. Impact of agriculture on soil consumption of atmospheric $\mathrm{CH}_{4}$ and a comparison of $\mathrm{CH}_{4}$ and $\mathrm{N}_{2} \mathrm{O}$ flux in subarctic, temperate and tropical grasslands. Nutr. Cycling Agroecosyst. 49: 71-83.

Mosier, A.R., C. Kroeze, C. Nevison, O. Oenema, S. Seitzinger, and O. Van Cleemput. 1998. Closing the global $\mathrm{N}_{2} \mathrm{O}$ budget: Nitrous oxide emissions through the agricultural nitrogen cycle. Nutr. $\mathrm{Cy}$ cling Agroecosyst. 52:225-248.

Mosier, A.R., W.J. Parton, D.W. Valentine, D.S. Ojima, D.S. Schimel, and J.A. Delgado. 1996. $\mathrm{CH}_{4}$ and $\mathrm{N}_{2} \mathrm{O}$ fluxes in the Colorado shortgrass steppe: I. Impact of landscape and nitrogen addition. Global Biogeochem. Cycles 10:387-399.

Mosier, A., D. Schimel, D. Valentine, K. Bronson, and W. Parton. 1991. Methane and nitrous-oxide fluxes in native, fertilized and cultivated grasslands. Nature (London) 350:330-332.

Müller, C., R.R. Sherlock, and P.H. Williams. 1997. Mechanistic model for nitrous oxide emission via nitrification and denitrification. Biol. Fertil. Soils 24:231-238.

Patrick, W.H., Jr. 1982. Nitrogen transformations in submerged soils. p. 449-465. In F.J. Stevenson (ed.) Nitrogen in agricultural soils ASA, CSSA, and SSSA, Madison, WI.

Petersen, S.O. 1999. Nitrous oxide emissions from manure and inor- 
ganic fertilizers applied to spring barley. J. Environ. Qual. 28: 1610-1618.

Petersen, S.O., A.L. Nielsen, K. Haarder, and K. Henriksen. 1992. Factors controlling nitrification and denitrification-A laboratory study with gel-stabilized liquid cattle manure. Microbiol. Ecol. 23:239-255.

SAS Institute. 1989. SAS/STAT user's guide. Version 6. 4th ed. Vol 2. SAS Inst., Cary, NC.

Schjoerring, J.K., S.G. Sommer, and M. Ferm. 1992. A simple passive sampler for measuring ammonia emission in the field. Water Air Soil Pollut. 62:13-24.

Sherlock, R.R., J.R. Freney, P.E. Bacon, and T.J. van der Weerden. 1995. Estimating ammonia volatilization from unsaturated urea fertilized and urine affected soils by an indirect method. Fert. Res. 40:197-205.

Sommer, S.G., and S. Husted. 1995. Chemical composition of the buffer system in livestock and biogas plant digested slurry. J. Agric. Sci. 124:45-53.

Sommer, S.G., and N.J. Hutchings. 2001. Ammonia emission from field applied manure and its reduction-Invited paper. Eur. J. Agron. 15:1-15.

Sommer, S.G., and J.E. Olesen. 2000. Modelling ammonia volatilization from animal slurry applied with trail hoses to cereals. Atmos. Environ. 34:2361-2372.

Sommer, S.G., and R.R. Sherlock. 1996. pH and buffer component dynamics in the surface layers of animal slurries. J. Agric. Sci. 127:109-116.
Sommer, S.G., R.R. Sherlock, and R.Z. Khan. 1996. Nitrous oxide and methane emissions from pig slurry amended soils. Soil Biol. Biochem. 28:1541-1544.

Steudler, P.A., R.D. Bowden, J.M. Melillo, and J.D. Aber. 1989 Influence of nitrogen fertilization on methane uptake in temperate forest soils. Nature (London) 341:314-316.

Thompson, R.B., B.F. Pain, and D.R. Lockyer. 1990. Ammonia volatilization from cattle slurry following surface application to grassland. I Influence of mechanical separation, changes in chemical composition during volatilization and the presence of the grass sward. Plant Soil 125:109-117.

Thornton, F.C., B.R. Bock, and D.D. Tyler. 1996. Soil emissions of nitric oxide and nitrous oxide from injected anhydrous ammonium and urea. J. Environ. Qual. 25:1378-1384.

Wilson, J.D., V.R. Catchpoole, O.T. Denmead, and G.W. Thurtell. 1983. Verification of a simple micrometeorological method for estimating the rate of gaseous mass transfer from the ground to the atmosphere. Agric. Meteorol. 29:183-189.

Willison, T.W., C.P. Webster, K.W.T. Goulding, and D.S. Powlson 1995. Methane oxidation in temperate soils-Effects of land-use and the chemical form of nitrogen-fertilizer. Chemosphere 30 539-546.

Wood, C.W., S.B. Marshall, and M.L. Cabrera. 2000. Improved method for field-scale measurement of ammonia volatilization. Commun. Soil Sci. Plant Anal. 31:581-590.

Zeikus, J.G., and M.R. Winfrey. 1976. Temperature limitation of methanogenesis in aquatic sediments. Appl. Environ. Microbiol. 31:99-107. 